\title{
Problematics of the Implementation of Mediation in the Pakam Deli Serdang Religious Court
}

\author{
Roswita Sitompul \\ Faculty of Law, Universitas Prima Indonesia \\ roswita_sitompul@yahoo.com
}

\begin{abstract}
Marriage is something that is considered very sacred in human life and it is as a family for humans to continue their offspring, every human tries to fight to maintain the plume of his household in order to survive, but in terms of the fact that many households have many problems due to many factors. The government in its position as a supervisor and to maintain the presence of community members establish PERMA NO 12016 which regulates that every case submitted to the Religious Court must be carried out with mediation. This research is descriptive empirical which data is sourced from primary and secondary data, data collection is done by conducting field research, observations and interviews. The results of the study shows that mediation is failed because: a. the lack of human resources in the Lubuk Pakam Religious Court because there are only 5 Judges, it is not comparable with the current cases and not all Judges can also act as Mediators. b. Unprofessional Attorney who only wants the case to be settled by litigation. $c$. The parties have unanimous their decision to divorce because they hold too long a longstanding grudge.
\end{abstract}

Keywords

problematics, application; mediation; religious court

\section{Introduction}

Every human being is a zoon politicon (social being), he cannot live alone but needs one another so that a peaceful life, prosperity and legal relationships are all bound by rules called norms. Likewise in marriage, every human being hopes that his marital life can be maintained in accordance with existing legal norms, because every legal relationship has rights and obligations, when the parties no longer pay attention to their rights and responsibilities, disputes arise both in family life and in Public.

The parties want to get legal certainty in resolving their cases, both civil and criminal cases through litigation trials which are considered the best thing for the community to obtain legal certainty, which is based on simple, fast and low cost principles but not in practice, case settlement in court is very difficult and requires a large amount of money.

Based on the foregoing, it is necessary to have Mediation as regulated in Article 130 Herziene Inlandsch Reglement and Article 54 Rechtreglement vor de Buitengewesten states that each judge must reconcile the parties before entering the trial process and which of the Judges continues to be included in the The question and answer trial process is deemed to have violated the procedure of proceeding at the Court, which consequently all decisions of the Judge, are null and void, meaning that they have never existed.

Based on the aforementioned matters, the Supreme Court issued Supreme Court Regulation (PERMA) No. 1 of 2008 concerning Mediation and was later replaced by PERMA No.1 of 2016 regulating the implementation of mediation procedures in Courts whose implementation is increasingly developing in the court process towards perfection.

In PERMA it is clear that the Judge in considering the decision of the case must state that the case in question has been attempted for peace through mediation by clearly stating the name of the mediator. 


\section{Research Methods}

This research is a descriptive empirical research with fact finding with the right interpretation. This descriptive research studies problems in society and certain situations, including relationships, activities, attitudes, views, and ongoing processes and the influence of a phenomenon. Secondary and primary data sources, data collection was carried out by conducting observational field research and interviews with the public who submitted their lawsuit to the Lubuk Pakam Religious Court and the Rearch library using books, journals, magazines, newspapers. The population in this study were 25 people consisting of: 10 household fathers and 10 housewives who were sued for divorce at the Lubuk Pakam Court as well as 2 lawyers and 2 judges as informants with details of 1 judge acting as mediator and 1 handling divorce cases because there was no agreement to mediate. This research includes empirical legal research, because it seeks to see law in a real sense, or how law works in society.

After the data is collected, all of them are analyzed which can provide an overview of how the mediation was carried out at the Lubuk Pakam Deli Serdang Religious Court, so that it can provide an idea of whether the mediation can be carried out properly and successfully or vice versa.

\section{Discussion}

Every civil case in court must enter the mediation process, except for cases that are resolved through the procedures of the Commercial Court, Industrial Relations court, objections to the decision on Consumer Dispute Resolution and objections to the decision of the Business Supervisory Commission in accordance with PERMA No.1 of 2008.

However, mediation in the Religious Courts is a way to resolve disputes between the parties by way of negotiation so that there is mutual agreement on the assistance of the mediator as a neutral party without going through court legitation which enforces a decision, and a mediator must be a person who has a mediator certificate issued by the Supreme Court.

Mediation is one of the alternatives to resolve disputes which consists of two parts, namely: a. Mediation outside the court which is handled by private parties, individuals or independent institutions which is better known as the National Mediation Center (PMN). $b$. mediation in court based on PERMA No. 2/2003, the mediation process must be carried out before the main examination of a civil case, where the mediator is a judge who does not handle the cases of the parties.

In the mediation process, the parties must be present either through a lawyer or person unless there is a valid reason, such as illness, there must be a certificate from a doctor or is domiciled abroad, professional claims or carrying out State duties must be with accurate evidence.

In mediating both parties in a court case must have good etiquette, that person does not have good etiquette if:

a. Did not attend the mediation process even though he had been summoned twice in succession

b. Attended the first mediation but did not attend the next meeting even though he had been summoned twice in succession.

c. Do not attend repeatedly so that it disturbs the schedule of the mediation trial

d. Not filing or not responding to case resumes.

e. Didn't sign a peace agreement. 
From a practical point of view in the field, often the plaintiff or defendant is determined to resolve the case by litigation so that even though he has been summoned in succession for mediation, he does not want to attend or does not care.

The legal consequences that arise if one of the parties does not have bad etiquette are:

a. The plaintiff's claim is said not to be accepted or (NO).

b. Plaintiffs are charged a mediation fee

c. In the mediation report, the plaintiff must be said that he does not have bad etiquette, along with a recommendation for sanctions and the amount.

d. The judge based on the mediator's report holds a trial and issues a verdict.

e. The mediation fee as a sanction is taken from a separate fee or financing by the plaintiff and submitted to the defendant.

In cases of divorce at the Religious Courts, the cost of mediation is borne by the defendant who will be submitted through the committee to the plaintiff following the implementation of the decision which already has permanent power. If the mediator says that both parties do not have bad etiquette, then the lawsuit is declared unacceptable by the judge examining the case without a mediation sentence.

The Religious Court is the first level court that resolves cases for people who are Muslim specifically for cases: marriage, inheritance, waqf grants, zakat, infaq, shadaqah, shari'ah economics.

Religious Court Judges have an obligation before entering the trial to:

1. It is obligatory to reconcile both parties, which should be attended by husband and wife

2. If the peace is successful, the divorce suit is withdrawn, if the peace fails, then the divorce suit will be continued in a closed session to the public.

Every initial trial in a civil case must begin with an offer for mediation by a Judge, the mediator is very different from the Judge or Arbitrator because the mediator does not have the authority to decide disputes, the mediator only gets power from the disputing parties to resolve the problems between them.

Marriage is something that is very sacred and everyone tries to make their marriage last until the grandparents but in reality this is not the case, as time goes on there are clashes in family life, so that it becomes untenable until divorce occurs. Divorce is something that God hates so much.

Divorce occurs due to many factors, this has an impact on the child, even though both parties feel relieved because the problem has been resolved, but how the child in the future creates a dilemma because during growth and development the child needs love from both parents.

In addition, awareness on self-empowerment is still very low and this is caused by many factors, among others: the low level of education which makes people to assume that women are naturally under men so that all activities carried out by them are geared towards helping with domestic work and devoting their lives to housework and family (Kariono, Badaruddin \& Humaizi, 2020). Currently there are developments in society and progress towards a more positive way of thinking and more and more wives are filing for divorce at the Religious Courts because women are now more inclined to choose divorce than withholding torture, this courage arises because many women have entered the field of work so that they have confidence in themselves and there is strong support from the family. According to Sitompul, Alesyanti \& Ridwan (2020) The Muslim women are allowed to divorce because this was permissible in terms of religion if it fulfilled the conditions set. 
Divorce in the city of Medan which is being tried by the Medan Religious Court has increased from 2018, there were 2509 cases and at the end of February 2019 there were 308 divorce cases. From the research results, it is the wife who dominates filing a divorce from her husband and in general are young brides aged 30 years and under.

A mediator must be able to gather as much positive information as possible, and be able to encourage the parties to open up to each other and listen to the parties' options, or the mediator will offer options to resolve the dispute to the parties.

The mediator as an intermediary must emphasize that the parties are not allowed to prosecute unreasonably and give the view that the decision taken is the best for both parties and is a mutual agreement that will not harm the parties meaning that the mediation has been successful if necessary the judge conducts a caucus. In the Karo community, the mediation is carried out by the new children (the virgin) from both parties who are in trouble.

A peace agreement occurs means that the dispute has been completely resolved by not using the principle of winning or losing. The peace agreement is not subject to the Judge's ordinary or extraordinary remedy.

Article 23 paragraph 1 of the Decree of the Supreme Court of Judges will strengthen the peace agreement if it meets the following requirements:

1. There is conformity with the will of the parties

2. Not against the applicable law

3. No third party feels aggrieved

4. The verdict can be executed

5. There is good etiquette for the parties

The decision of the peace certificate for both parties may not be added or decreased by the judge who has the right to resolve the cases of the parties and confirm the peace decision by giving the title of execution.

The mediation decision is the same as the legal force of the Court decision:

a. Having permanent power (Article 130 HIR) (2) and Article 1858 of the Civil Code means that if one of the parties breaks their promise not to do what is agreed in the peace agreement, the injured party will ask the Court to carry out the execution.

b. Has executorial power.

c. The peace deed is executorial directly attached, if one of the parties does not carry it out then it can ask the Court to carry out the execution (exsecutoriale kracht). Execution is an act of coercion by the Court if the losing party does not make a decision voluntarily.

d. The mediation decision cannot be appealed, meaning that no legal remedy can be made, be it an appeal or cassation.

From the practical point of view in the field that the failure of a mediation in divorce cases is due to:

1. The absence of a good mindset for lawyers and the parties concerned.

2. The explanation of the majlis has not been optimal so that the parties do not understand mediation.

3. The existence of a mindset for lawyers to be litigated based on winning or losing.

In the table below, you can see how many cases were submitted and registered at the Lubuk Pakam Religious Court that were successfully resolved by mediation. 
Table 1. Cases included in mediation

\begin{tabular}{|c|c|c|c|c|}
\hline Year & $\begin{array}{c}\text { Number of Cases } \\
\text { which is in } \\
\text { Mediation }\end{array}$ & $\begin{array}{c}\text { Not } \\
\text { feasible } \\
\text { Mediation }\end{array}$ & \multicolumn{2}{|c|}{ Mediation Cases } \\
\hline & & & It works & Not successful \\
\hline 2016 & 302 & - & 5 & 297 \\
\hline 2017 & 289 & 214 & 10 & 65 \\
\hline 2018 & 375 & 2310 & 7 & 368 \\
\hline Amount & 966 & 2524 & 22 & 730 \\
\hline
\end{tabular}

Source: Lubuk Pakam Religious Court Report

In the table above, it can be seen that in the span of three years from 2016 to 2018 , only in 2018 the highest number of cases was mediated, namely 375 cases and the most cases that were not feasible in Mediation were also in 2018 as many as 2310, this happened because:

1. There is no agreement between the parties for 30 days and another 30 days extension after the specified time

2. One of the bonded parties is not good because:

3. Participates in Mediation but does not respond to opposing party resumes

4. Refusing to sign an agreement for no apparent reason

5. Mediation that is not feasible must be notified to the judge who will handle the case because:

a. Involvement of third party assets that are not mentioned in

b. lawsuit so that they cannot be parties to the mediation

c. Involvement of State institutions that are not included as parties in the case.

d. Absent without unauthorized reasons.

The highest number of cases that succeeded in mediation was in 2017, 10 cases meaning that the case was no longer continued and the case was withdrawn, the Judge succeeded in holding Mediation to the parties, it needs to be thumbs up because it is very difficult to achieve successful mediation in divorce cases because of grudges due to disputes which is late. However, the highest number of unsuccessful cases in mediation was in 2018, namely: 368 cases then followed in 2016 as many as 297 cases.

So in the Lubuk Pakam Religious Court the number of cases mediated from 2016 to 2018 was 966 cases and those that were not eligible in Mediation were 2524 cases, meaning that judges in handling divorce cases at the Religious Courts must be careful because not all of the cases filed by the parties can in mediation because it is possible that in the continuation of one's household life it involves the assets of a third party who are not included as parties in the case so that mediation cannot be carried out and there are also other reasons because there is no agreement between the parties in the case to bring the case into mediation.

In addition, 22 successful cases in Mediation mean that there are 22 couples who are on the verge of divorce who may still be able to fully run the household or otherwise divorce has occurred but there is agreement from both parties to mediate in terms of maintaining child custody and legal interests in property. the wealth of minors. Then those that did not succeed in mediation were 730 cases, meaning that there were as many cases related to everything related to ongoing marital divorce in trials at the Lubuk Pakam Religious Court from 2016 to 2018.

If the mediation does not reach an agreement, the mediator submits it in writing that the mediation process has failed and reports it to the panel judge who is examining it. The 
case examining judge remains authorized to destroy the peace until before the pronouncement of the decision.

If the mediation fails, the statements and confessions of the parties in the mediation process cannot be used as evidence at trial.

However, if the mediation reaches an agreement the parties are obliged to appear before the judge by bringing the result of the agreement signed by both parties, by:

1. Requesting that the outcome of the agreement be contained in a peace decision (deed of dading). The peace certificate is signed by the appellate judge, cassation, and reconsideration within 30 working days from the time it is recorded in the case registration.

2. To withdraw the lawsuit as referred to in the clause that must be included in the agreement, if the result of the agreement does not want to be included in the decision.

So in terms of practice in the field, the judge still offers mediation even though it is already in the process of appeal, cassation

Based on Law No. 8 of 2008 (5) a mediator must have a certificate issued by the agretation agency by the Supreme Court to demonstrate his professionalism, qualification and high integrity in order to be able to provide justice in mediation decisions.

The mediator must be able to arouse feelings from both parties, especially the result of the divorce of the child which may cause the child to become drugs or be involved in other crimes, usually both of them quickly melt away, even though they are still divorced but there is mediation regarding child custody and property, for the benefit of the child who are underage.

It is indeed very difficult to mediate in divorce cases due to infidelity and economic reasons because in general divorce cases go to court, the incident has dragged on to be like an old and deep wound like a fairly chronic disease.

Here the mediator helps the parties to analyze the options for resolving the dispute and firmly recommends not to make claims that do not make sense. The mediator assures the parties that the decision made is the best thing and the mediator always makes terms of the agreement that do not harm either party so that neither party feels disadvantaged, the last agreement is the end of the mediation session. If necessary, the judge conducts a caucus.

Judges in this case may not add to or tarnish the peace decision of both parties from the contents of the deed that have been made, take over the entire peace agreement then the peace agreement is handed over to the judge who hears the case to confirm the peace decision by giving the title of execution.

The legal force of a mediation conducted by the Mediator in court is the same as the Court's decision.

a. Has legal force.

In Article 130 Herzieni Inlandssh Reglement (2) the peace deed that is made in court has legal force which remains similar to a court decision which has permanent legal force (Article 1858 paragraph 1 of the Civil Code) which means that it gives the same consequences, namely if one of the parties breaking the promise not to carry out what is stated in the contents of the peace, the party who feels aggrieved can ask the court to carry out the execution

b. Has executorial power.

c. Every decision on a peace deed has direct executorial power, so that if the decision is not made by one of the parties then it can be asked for coercion on the Court to carry out an exsecution (exsecutoriale kracht). 
Exsecution is an act of coercion carried out by the court if the losing party does not carry out the contents of the decision voluntarily.

d. Cannot be appealed.

This means that no more legal remedies are made, whether appeal or cassation, because it is the highest decision and this system is very efficient and effective.

The Religious Court is a court of first instance only functions to resolve cases of Muslims specifically in cases of: marriage inheritance, donation of zakat, infaq, shadaqah, shari'ah economics.

Divorce is something that is hated by God, therefore Allah says you can marry two, three and four if you can be fair. Divorce has an impact on the child, although both parties feel relieved because the problem has been resolved, but how the child in the future creates a dilemma because during the development period the child needs love from both parents.

In the positive law there are also several factors in the occurrence of divorce according to Law No.1 of 1974, namely: if one of them commits adultery, gets a prison sentence of two consecutive years for drunkenness, leaves one party for two consecutive years, commits cruelty (severe maltreatment), is physically disabled so that they cannot do their duty as husband / wife, constant quarrels.

At present there are developments in the factors of divorce other than what has been stipulated by law, which have been registered at the Lubuk Pakam Religious Court can be seen in the table below;

Table 2. Factors Causing Divorce

\begin{tabular}{|c|c|c|c|c|}
\hline No & Reason & $\mathbf{2 0 1 6}$ & $\mathbf{2 0 1 7}$ & $\mathbf{2 0 1 8}$ \\
\hline 1 & Adultery & 73 & 170 & - \\
\hline 2 & Drunk & 102 & 155 & 161 \\
\hline 3 & Opium & 21 & 25 & 331 \\
\hline 4 & Gambling & 73 & - & 161 \\
\hline 5 & Leave one party & 594 & 615 & 429 \\
\hline 6 & In Criminal Law & 22 & 25 & 45 \\
\hline 7 & Polygamy & - & - & - \\
\hline 8 & Domestic violence & 69 & 104 & 77 \\
\hline 9 & Disability & 1 & - & - \\
\hline 10 & Continuous bickering & 544 & 355 & 657 \\
\hline 11 & Forced marriage & - & - & - \\
\hline 12 & Apostate & 2 & - & - \\
\hline 13 & Economy & 25 & 166 & 133 \\
\hline & Amount & 1526 & 1615 & 1994 \\
\hline
\end{tabular}

Source: Lubuk Pakam Religious Court Annual Report

The table above shows that the reasons for divorce registered at the Lubuk Pakam Religious Court starting from 2016 to 2018 were dominated by reasons: a. Continuous contentious dispute b. One party leaves the other c. Madat d. adultery e. Drunk and gambling e. Economy f. Domestic violence.

Then it was followed by one party leaving the other party either because of the choice of men (pill) or because of will (the woman of choice), there were 615 cases in 2017 illustrating that society today is increasingly unfaithful about the promise of a marriage determined by law. said that marriage is based on the one and only Godhead and aims to create a happy and eternal household while according to the Koran, marriage is worship to form a sakinah and mawardah household. 
However, if the divorce case occurs because of the presence of a third party, it can still be analyzed in a social perspective, there is only one solution to avoiding divorce, namely: understanding each other and accepting partner shortcomings and discussing solving problems and complementing each other in shortcomings and not complementing each other's strengths.

The third rank followed by madat in 2018 as many as 331 cases are a crime that is prohibited by law which arises because of the influence of the association and the environment of the parties, there is a reason this divorce is not contained in the Marriage Law No.1 of 1974 namely drugs are one of the reasons for divorce arising from the development of the era, there is not much hope of sustaining a family life if one of the parties is addicted to drugs because this is a mental and physical destroyer, the person is no longer thinking about the future of his family and children. His life is only enough if he has used drugs and for the sake of the drug concerned he can do anything for his needs to consume the illegal goods.

Then Zina, which is in the fourth place for divorce reasons at the Lubuk Pakam Religious Court, shows that people who are Muslim in the legal environment of the Lubuk Pakam Religious Court are no longer afraid of Allah's law because it is written in the Koran that whoever commits adultery then 40 doors from where the parties do that will immediately get the hazab of Allah SWT.

The fifth rank of economic factors, this is the importance of pre-marital guidance carried out by the KUA before the parties marry so that the parties understand each other and understand life, there must be good cooperation to maintain the integrity of family life and what the weaknesses of the parties are to be fought for to become a common strength. In marriage counseling it is necessary to emphasize the strength of complete cooperation so that it is not due to economic reasons that the husband is less fortunate, the wife also has to roll up her sleeves to work together to maintain the family so it does not become fragile resulting in divorce, followed by drunkenness and gambling in 161 cases. in 2018 and there were 104 cases of domestic violence in 2018. If there is a divorce suit it is due to domestic violence and drug use. This leads to the realm of criminal law and is resolved legally.

All the reasons for the divorce illustrate the lower recognition of faith from the community in the legal area of the Lubuk Pakam Religious Court, it must be realized by all Indonesian parents that our life is very difficult, if the children have been affected by the consequences of divorce from both parents and without any more control if both parents of children can be separated from drug crimes, it means that consciously or unconsciously, our descendants will no longer contribute to the State because people who are physically and mentally healthy can contribute to our beloved country. Here it is important that the role of religious leaders must be functioned as soon as possible to make the Lubuk Pakam community aware of the love and blessings of Allah SWT for their life that they are still given physical health, not to waste the time given by Allah for the needs of mere bodily desires.

It is true that the divorce is indeed a relief for the parties, but on the other hand there is a very heavy effect for children who still need a case of love and education from their parents to lose the future of our Indonesian children, which must be fought for in the early morning to achieve the goals of our country, Indonesia because of the State. Indonesia depends on the younger generation.

The government and the private and private society must be equally responsible for fighting for the future of the next generation of the Indonesian nation so that this country 
can be mortgaged because our younger generation is not ready because of the influence of the lives of their parents.

The existence of something that is considered special in race, ethnicity, origin, and religion (Saragih et al, 2019). The government in this case needs to hold prenuptial training because the dimensions needed for the integrity of a household, namely religion, social, and religion, of course, require various preparations for marriage so that marriage is carried out with a good plan. In Indonesia, there is no requirement for a person to be married, to go through a pre-marriage provision. The Ministry of Religion has indeed provided such a forum but it is only attended by a handful of couples. Based on the observations of the researchers, those who underwent practical pre-marital training seemed not interested, because they easily left the activity even though it had not ended. This situation is even more sad, because from the Ministry of Religion there is no requirement for those who are going to register for marriage, they must obtain a certificate that has gone through premarriage preparations. The pre-marriage course held at the Ministry of Religious Affairs in Medan is a preventive step to minimize problems in the household in the future. The Candidate Bride Course is the provision of knowledge, understanding, and skills in a short time to catin (prospective bride and groom) about household / family life. The purpose of the issuance of this regulation is to increase understanding and knowledge of household / family life in realizing family sakînah, mawaddah and rahmah and reducing the number of disputes, divorces and domestic violence.

\section{Conclusion}

In reality, divorce is a dominant case in the Religious Court in Lubuk Pakam, where in general, household life is no longer possible to sustain even though the parties concerned have tried to resolve it by involving the family of the customary elders and the parents in the family.

The unsuccessful mediation at the Lubuk Pakam Religious Court was due to the lack of desire of the parties and the lack of judges who were capable of being mediators. Because in the Lubuk Pakam Hakim religious court there were only 15 people and human resources played an important role in mediation

Mediation is carried out to avoid decreasing the number of divorces because the divorce has a very broad effect, especially on children who still need love from both parents in managing their future.

\section{References}

As, A., E. (2012). Hukum Acara Perdata Dalam Prespektif Mediasi (ADR) di Indonesia, Yokyakarta: Graha Ilmu.

Gary, G. (1993). Negoisasi dan Mediasi : Sebuah Pedoman Negoisasi dan Penyelesaian Sengketa Melalui Mediasi, Jakarta : ELIPS Project

Kariono, Badaruddin, Humaizi (2020): A study of women's potential and empowerment for accelerating village development in Serdang Bedagai district, North Sumatera Province, Community, Work \& Family, DOI: 10.1080/13668803.2020.1735302

Muhammad, A., K. (2004). Hukum Dan Penelitian Hukum. Bandung: PT Citra Aditya Bhakti.

Nugroho, A., Susanti. (2009). Mediasi Sebagai Alternatif Penyelesaian Sengketa, Jakarta: Telaga Ilmu Indonesia 
Raharjo, T. (2011). Mediasi Pidana Dalam Sistim Peradilan Pidana Suatu Kajian Perbandingan dan penerapannya di Indonesia (Jokjakarta : Buku Litera)

Roswita. Sitompul, A. Alesyanti, H. Hartono, and A. S. Ahmar. (2018). "Revitalization Model The Role of Tigo Tungku Sajarangan in Fostering Character of Children in Minangkabau Family and Its Socialization Through Website," International Journal of Engineering \& Technology, vol. 7, no. 2.5, pp. 53-57, Mar.

Roswita Sitompul, A. Alesyanti, H. Hartono, and R. Rahim. (2018). "Legal Protection for Children Born from Unregistered Marriage in Medan City and Its Socialization Through Website," International Journal of Engineering \& Technology, vol. 7, no. 2.14, pp. 246-250.

Sitompul, R., Alesyanti, Ridwan, M. (2020): Domestic violence as initiated by Batak culture in East Medan, Indonesia, Journal of Human Behavior in the Social Environment, DOI: 10.1080/10911359.2020.1750526

Saragih. H, et al. (2019). The struggle of Batak Simalungun for their identity in Church organization in Simalungun, Medan, Indonesia, Journal of Human Behavior in the Social Environment, 29:6, 693-704, DOI: 10.1080/10911359.2019.1590888

Sembiring, Milisi. (2018). The Role of Rakut si Telu in Karonese Society. Komunitas: International Journal of Indonesian Society and Culture, vol. 10, no 1 Semarang State University, Indonesia

Sumarto, G. (2006). Undang-undang Tentang Arbitrase dan Mediasi di Indonesia Jakarta: Gramedia

Syahrizal, A. (2011). Mediasi Dalam Hukum Syariah, Hukum Adat dan Hukum Nasional, Jakarta: Kencana. 